\title{
Opinion of health professionals and drug users before the forthcoming opening of the first drug consumption room in Paris: a quantitative cross-sectional study
}

Grégoire Cleirec ${ }^{1}$, Maeva Fortias², Vanessa Bloch', Virgile Clergue-Duval 2,3,4, Frank Bellivier 2,3,4, Thomas Dusouchet ${ }^{5}$, Céline Debaulieu ${ }^{5}$ and Florence Vorspan ${ }^{2,3,4^{*}}$ (D)

\begin{abstract}
Background: On the brink of the opening of the first French drug consumption room in Paris, the general opinion of the local involved health care professionals and drug users was not known. The objective of this study was to determine their expectations and to search for influencing factors.

Method: We carried out a quantitative cross-sectional study. A multiple choice questionnaire was proposed to the surrounding willing general practitioners (GPs) and pharmacists, to the emergency doctors of Lariboisière hospital, and to the professionals of the harm reduction facilities and their drug users (PWUD). For each question, there was a choice between seven answers, from " -3 " (very negative impact) to " 3 " (very positive impact). The influence of the characteristics of each group on its mean answers was explored by Mann-Whitney, Kruskal-Wallis, and Spearman's tests.
\end{abstract}

Results: The median expectations among the groups of responding GPs $(N=62)$, other health care professionals ( $N=82)$, and PWUD $(N=57)$ were mainly positive. They thought that the drug consumption room (DCR) would improve the health of PWUD, reduce their at-risk behaviors, would not increase drug use or drug dealing in the neighborhood, and would reduce nuisance in the public space. Only the group of GPs expressed that the DCR could decrease the quietness of the neighborhood, and only the group of PWUD had higher expectations that the DCR would decrease the number of arrests and the number of violent behavior. GPs' expectations were significantly better in terms of health improvement of PWUD and reducing their precariousness if they had a previous experience in addiction medicine (Mann-Whitney, $p=0.004$ and $p=0.019$ ), with a longer practice (Spearman's rho, $p=0.021$ and $p=0.009$ ), and if they were currently prescribing opioid substitution treatments (Mann-Whitney, $p=0.030$ and $p=0.002$ ).

Among non-GPs, those who were working in addiction medicine centers had significantly better expectations than pharmacists, and the professionals of the local emergency department had intermediate expectations.

Conclusions: Health care professionals and drug users had a positive opinion of the to-be-created Parisian drug consumption room. Experience in addiction medicine influenced positively health professionals' expectations.

Keywords: Drug consumption room, Supervised injection facility, Intravenous drug users, Opiates, Crack/cocaine, General practitioner, Pharmacists, Emergency doctors, France

\footnotetext{
* Correspondence: florence.vorspan@aphp.fr

${ }^{2}$ Département de Psychiatrie et de Médecine Addictologique, Hôpital

Fernand Widal, APHP, Paris, France

${ }^{3}$ Faculté de Médecine, Université Paris Diderot, Paris, France

Full list of author information is available at the end of the article
}

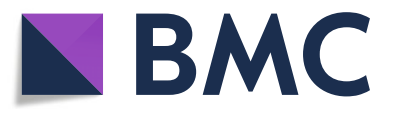

(c) The Author(s). 2018 Open Access This article is distributed under the terms of the Creative Commons Attribution 4.0 International License (http://creativecommons.org/licenses/by/4.0/), which permits unrestricted use, distribution, and reproduction in any medium, provided you give appropriate credit to the original author(s) and the source, provide a link to the Creative Commons license, and indicate if changes were made. The Creative Commons Public Domain Dedication waiver (http://creativecommons.org/publicdomain/zero/1.0/) applies to the data made available in this article, unless otherwise stated. 


\section{Background}

Drug consumption rooms (DCRs) are facilities operated by social workers, nurses, and medical doctors intended to provide a safe, hygienic, and therapeutic environment for the consumption of pre-obtained drugs, under professional supervision and in a non-judgmental environment [1-3]. Their primary goal is the outreach and health improvement of marginalized people who use drugs (PWUD). Their secondary goals are the reduction of drug use-related health risks (such as HIV or HCV infection, overdoses, skin and soft tissues infection or lesions secondary to drug injection), the improvement of health care of PWUD, and providing them with the opportunity to meet social workers. DCR can indirectly decrease drug-related public disorders (such as public drug use, smoking and injection devices abandoned in public space, drug-related violence, drug trafficking) [1-3]. They are also careful to coordinate their practice in the local security policy (working with mayors and law enforcement forces) in order not to promote drug use or increase drug-related crime [1, 2, 4].

The first DCR opened in Bern, Switzerland, in 1986 [1]. It was mainly intended to reduce the economic and health consequences of the HIV epidemic among PWUD and the public nuisance linked to the important local open drug scene [5]. Other facilities then opened in Germany and the Netherlands in the 1990s, and today, more than 90 DCRs have been established in nine countries [5]. Originally designed for the injection of drugs, now DCRs often also allow the inhalation of substances $[1,6]$.

The efficiency of DCRs regarding their different objectives has been demonstrated, although it has been argued that most of the studies originated from only two cities (Sydney and Vancouver) and that more European studies aiming to evaluate DCRs would be warranted [7]. More specifically, it has been shown that (i) DCRs reduce overdose-induced mortality [8] and increase the access to addiction treatment programs $[9,10]$; (ii) DCRs reduce syringe sharing and syringe reuse and provide education on safer injection practices $[11,12]$, with different estimations on the extent to which they participate in reducing viral transmissions of $\operatorname{HIV}[13,14]$; (iii) DCRs do not have the adverse effect of inciting drug use, since they are not related to any increase of the number of PWUD or of the amount of drug consumed by PWUD [15]; (iv) DCRs reduce injections and injection-related waste in the public space [16] and do not increase drug-related crime, violence, and trafficking $[1,2,4,17,18]$.

In France, the debate regarding the opening of DCRs has been going on since the 1990s [19]. Before a law passed in 2016, harm reduction programs could provide injection material (such as needles, syringes) but were not allowed to have PWUD injecting in their facilities.
Furthermore, only methadone and buprenorphine oral maintenance treatment are approved in France and there is no care facility allowed to provide prescribed injectable heroin or morphine as a maintenance treatment. In 2010, the report commissioned by the Ministry of Health to the research institute INSERM on harm reduction was in favor of the opening of DCRs in France [20], but a controversy persisted [21]. The experimentation of DCR has been finally voted in January 2016, and the first DCR opened in Paris on the 10 October 2016 in the 10th district of Paris, next to North end station and adjoining Lariboisière general university hospital. This district had an open drug scene, especially with users dealing and using intravenously morphine sulphates [22].

Some studies emphasized that the acceptability of DCR depends in part of the previous assessment of the opinion of the involved people [23]. On the brink of the opening of the first French DCR, the opinion of the French drug users regarding such a facility had not been investigated. The opinion the surrounding general practitioners (GPs) had been evaluated by one study conducted in 2015, in which $61.5 \%$ of the GPs working in the neighborhood of the future DCR declared themselves in favor of its opening [24]. The opinion of others health professionals involved with PWUD, such as pharmacists, emergency room doctors, and addiction care/ harm reduction professionals, was not known.

In the international literature, the opinion of PWUD regarding DCR has been extensively investigated in several countries: surveys and qualitative studies have shown that they were predominantly in favor of DCRs in Canada, Australia, Denmark, UK, and in the USA [25-30].

The opinion of the emergency doctors in Canada is also known: $74.5 \%$ of the respondents were in favor in the implementation of DCRs, and $84.6 \%$ of them would refer patients to DCR if they did exist [31].

To our knowledge, no other international study has researched the opinion of the other health professionals directly involved with PWUD regarding DCRs.

This is why, shortly before the opening of the first French DCR in Paris, we conducted this study to determine the opinion of the nearby, GPs, pharmacists, emergency doctors, harm reduction professionals, and PWUD regarding the consequences of this opening. The secondary objective was to look for factors influencing this opinion.

\section{Methods}

We carried out a quantitative cross-sectional study.

The inclusion criterion for the GPs and the pharmacists was to work in the 9th, 10th, and 18th district of Paris (districts that are in the surroundings of the site of the DCR, and are known to hold a population of socially disadvantaged drug users). The inclusion criterion for the emergency doctors was to work in the emergency 
room of Lariboisière hospital (adjoining the location of the DCR). The inclusion criteria for the harm reduction professionals was to work in an addiction care or harm reduction facility of the 9th, 10th, 18th, and 19th districts. The inclusion criteria for the PWUD were to be over 18 years old (the French age of majority), to use or to have used an illegal drug and to visit a care or harm reduction facility of the area, where they were recruited.

We created a multiple choice questionnaire (MCQ) based on the positive and negative goals of the DCRs, reformulated as 14 items (see Table 1). The MCQ had 14 questions about the impact of the opening of the DCR regarding each item. For each question there was a choice between 7 answers, each corresponding to a numerical value ranging from -3 to +3 , " 0 " meaning "non influence". These 14 questions were similar for all the groups.

The study design was approved by the INSERM IRB (CEEI-IRB00003888) on July 2016.

The answers to the questionnaire were organized in four categories, describing the potential impact of the opening of the DCR on the following: the health of PWUD, the social welfare of PWUD, an effect of trivialization and incitement of drug use, and the effect on drug-related public disorders.

We created three sets of questions assessing the social and professional characteristics of the GP, of the health professionals that were not GPs, and of the drug users. GPs were asked about their age, their sex, the district in which they worked, the prescription of opioid substitution treatment (OST) in their practice or not, and their experience in managing patients with substance use disorders. The other health professionals were asked about their age, their sex, the district in which they worked, their past experience in the field of addiction medicine in years, and their occupation (pharmacist, emergency doctor, or worker in an addiction care or risk reduction facility (including doctor, nurse, social worker, counselor, director)). Because most of those professionals were not medical doctors, the question of OST prescription was not evaluated in this group. PWUD's characteristics were not analyzed in this study.

We contacted by phone every GP and pharmacy listed in the phone book as working in the 9th, 10th, or 18th district at the beginning of the summer 2016. If they were interested in the study, we offered to send them an email with a link directing to the online questionnaire and an information form summarizing the objectives and the method of the study, or to fax them these documents. We contacted the head of the emergency department in Lariboisière hospital, who forwarded an email with a link directing to the online questionnaire and an information form to every doctor working in this ER. The heads of every care or harm reduction facility of the 9th, 10th, 18th, and 19th districts of Paris were contacted by phone and/or email. If they agreed to it, the main investigator came to present the study during a staff meeting and ask the willing members of the staff to fill up a printed questionnaire. In the willing harm reduction facilities, anonymous questionnaires and information forms were also left for the PWUD who attended them. The local staff was trained to the study requirement. They were in charge of the information on the study, its purpose, and its anonymity and offered PWUD to participate. The interested PWUD could read the information form and complete the questionnaire alone or with the help of a staff member. Since there was no obligation to participate to the study, filling up the questionnaire amounted to consent. The main investigator collected the completed questionnaires before the opening of the DCR too. Responses were anonymous in all groups.

The statistical analysis was done with SPSS 21.0. For the 14 questions regarding the DCR, the medians and the means of the numerical answers of each group are described (the median was considered as the main result). For the two groups of GPs and other health professionals, univariate comparisons were performed to test the association of the collected variables and the expectations. Because normality assumptions were not always met, we choose to perform only non-parametric tests (Mann-Whitney $U$, and Kruskal-Wallis tests or Spearman's correlation tests as appropriate).

\section{Results}

We conducted the study during the summer 2016, before the opening of the Parisian DCR in October 2016. Out of the 251 GP of the target population, 119 accepted to receive a questionnaire and 62 effectively participated in the study (24.7\%), they formed the first group. Out of the 162 pharmacies of the territory of the study, 72 accepted to receive questionnaires and 30 pharmacists completed them. Out of the 29 doctors working in the ER of Lariboisière hospital, 5 completed a questionnaire (17.5\%). Out of the 14 harm reduction facilities of the north of Paris, 9 accepted to participate to the study, of which 45 workers completed the questionnaire. The latter three constituted the group of "other health workers" $(N=82)$. Finally, 57 PWUD from those 9 harm reduction facilities completed a form.

\section{Results among GPs}

The median answers in the GPs were that the DCR would improve the health of PWUD (decrease of the sharing of smoking and injection devices, of the deaths by overdose, and of the drug-related infections, and improvement of the access to health care and global health of PWUD). They also thought that the DCR would have no influence on the access to social welfare for PWUD, that it would not have an effect of trivialization and 
Table 1 Multiple choice questionnaire distributed to all the participants

\begin{tabular}{|c|c|c|c|c|c|c|}
\hline $\begin{array}{l}\text { A lot less health care } \\
\text { access } \\
(-3)\end{array}$ & $\begin{array}{l}\text { Less health care } \\
\text { access } \\
(-2)\end{array}$ & $\begin{array}{l}\text { A bit less health care } \\
\text { access } \\
(-1)\end{array}$ & $\begin{array}{l}\text { No } \\
\text { influence } \\
\text { (0) }\end{array}$ & $\begin{array}{l}\text { A bit more health care } \\
\text { access } \\
(+1)\end{array}$ & $\begin{array}{l}\text { More health care } \\
\text { access } \\
(+2)\end{array}$ & $\begin{array}{l}\text { A lot more health } \\
\text { care access } \\
(+3)\end{array}$ \\
\hline
\end{tabular}

2) According to you, how will the DCR influence the frequency of drug use of PWUD?

\begin{tabular}{|c|c|c|c|c|c|c|}
\hline $\begin{array}{l}\text { A lot less drug use } \\
(-3)\end{array}$ & $\begin{array}{l}\text { Less drug use } \\
(-2)\end{array}$ & $\begin{array}{l}\text { A bit less drug use } \\
(-1)\end{array}$ & $\begin{array}{l}\text { No } \\
\text { influence } \\
(0)\end{array}$ & $\begin{array}{l}\text { A bit more drug use } \\
(+1)\end{array}$ & $\begin{array}{l}\text { More drug use } \\
(+2)\end{array}$ & $\begin{array}{l}\text { A lot more drug use } \\
(+3)\end{array}$ \\
\hline
\end{tabular}

3) According to you, how will the DCR influence the risk of injection-related infectious diseases?
A lot less infections Less infections
A bit less infections
No A bit more infections
More infections
A lot more infections $(-3)$$$
(-2)
$$
influence $(+1)$
$(+2)$
$(+3)$

4) According to you, how will the DCR influence the risk of death by overdose?
A lot less deaths
Less deaths
A bit less deaths
$\begin{array}{ll}\text { No } & \text { A bit more deaths } \\ \text { influence } & (+1)\end{array}$
More deaths
$(-3)$
$(-2)$
$(-1)$
(0)
$(+2)$
A lot more deaths

5) According to you, how will the DCR influence the social vulnerability of PWUD?
A lot less vulnerable
Less vulnerable
A bit less vulnerable
No A bit m
A bit more vulnerable
$(-3)$
$(-2) \quad(-1)$
influence $(+1)$
More vulnerable
$(+2)$
A lot more vulnerable (0)
$(+3)$

6) According to you, how will the DCR influence the sharing of used smoking and injection devices?

\begin{tabular}{|c|c|c|c|c|c|c|}
\hline $\begin{array}{l}\text { A lot less sharing } \\
(-3)\end{array}$ & $\begin{array}{l}\text { Less sharing } \\
(-2)\end{array}$ & $\begin{array}{l}\text { A bit less sharing } \\
(-1)\end{array}$ & $\begin{array}{l}\text { No } \\
\text { influence } \\
\text { (0) }\end{array}$ & $\begin{array}{l}\text { A bit more sharing } \\
(+1)\end{array}$ & $\begin{array}{l}\text { More sharing } \\
(+2)\end{array}$ & $\begin{array}{l}\text { A lot more sharing } \\
(+3)\end{array}$ \\
\hline
\end{tabular}

7) According to you, how will the DCR influence the amount of new PWUD?

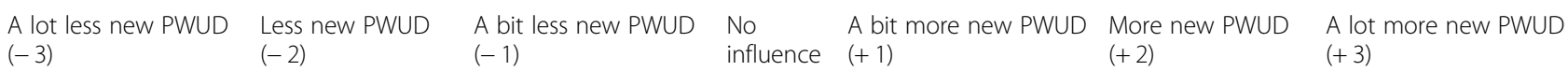
(0)

8) According to you, how will the DCR influence the number of arrests for drug use?
A lot less arrests
Less arrests
A bit less arrests
No A bit more arrests
influence $(+1)$
More arrests
A lot more arrests
$(-3)$
$(-2) \quad(-1)$
$(+2)$
$(+3)$

(0)

9) According to you, how will the DCR influence the quietness of the neighborhood?
A lot less quiet
Less quiet
A bit less quiet
No A bit quieter
influence $(+1)$
Quieter
$(+2)$
A lot quieter

(0)

10) According to you, how will the DCR influence the amount of injection or smoking devices abandoned in the public space?

\begin{tabular}{|c|c|c|c|c|c|}
\hline andone & $\begin{array}{l}\text { Less abandone } \\
\text { devices } \\
(-2)\end{array}$ & $\begin{array}{l}\text { A bit less abandoned } \\
\text { devices } \\
(-1)\end{array}$ & $\begin{array}{l}\text { No } \\
\text { influence } \\
\text { (0) }\end{array}$ & $\begin{array}{l}\text { A bit more abandoned } \\
\text { devices } \\
(+1)\end{array}$ & $\begin{array}{l}\text { More abandoned } \\
\text { devices } \\
(+2)\end{array}$ \\
\hline
\end{tabular}

11) According to you, how will the DCR influence the importance of drug dealing in the neighborhood?
A lot less drug
Less drug dealing A bit less drug
No A bit more drug
influence dealing
More drug dealing dealing

$(-2) \quad$ dealing
(0) $\quad(+1)$
$(+2)$
A lot more drug
$(-1)$

12) According to you, how will the DCR influence the use of drug in public in the neighborhood?
A lot less drug use in
Less drug use in
public
A bit less drug use in
No
A bit more drug use in public
$(-3)$
$(-2)$
$(-1)$
(0) $\quad(+1)$
More drug use in public
$(+2)$
A lot more drug use in public

13) According to you, how will the DCR influence the risk of violence in the neighborhood?
A lot less violence
Less violence
A bit less violence
$\begin{array}{ll}\text { No } & \text { A bit more violence } \\ \text { influence } & (+1)\end{array}$
More violence
$(+2)$
A lot more violence
$(-3)$
$(-2) \quad(-1)$
(0)
$(+3)$ 
Table 1 Multiple choice questionnaire distributed to all the participants (Continued)

\begin{tabular}{|c|c|c|c|c|c|c|}
\hline $\begin{array}{l}\text { Health a lot worst } \\
(-3)\end{array}$ & $\begin{array}{l}\text { Worst health } \\
(-2)\end{array}$ & $\begin{array}{l}\text { Health a bit worst } \\
(-1)\end{array}$ & $\begin{array}{l}\text { No } \\
\text { influence }\end{array}$ & $\begin{array}{l}\text { Health a bit better } \\
(+1)\end{array}$ & $\begin{array}{l}\text { Better health } \\
(+2)\end{array}$ & $\begin{array}{l}\text { Health a lot better } \\
(+3)\end{array}$ \\
\hline
\end{tabular}

Abbreviations: $D C R$ drug consumption room, $P W U D$ people who use drugs Italic prints: $p<0.05$

incitement of drug use (no influence on the number of new PWUD and on the frequency of drug use). Their opinion was mixed regarding the impact on drug-related public disorders (they thought that the DCR would decrease the tranquility of the neighborhood, but would have no influence on the violence, the number of arrests for drug use, or the drug dealing, and would result in a decrease of drug consumption in the public space and of the amount of abandoned injection and smoking devices) (see Table 2).

The univariate analysis revealed that age, sex, or district of exercise were not significantly associated with a different expectation. Reversely, GPs who declared that they had experience in addiction medicine, with the longer duration of this experience, and that they currently prescribed OST had significantly higher expectancies that the DCR would improve the access to social rights of PWUD (respectively MW $p=0.019$, Spearman's rho $p=0.009$ and MW $p=0.030$ ) and their health condition (respectively MW $p=0.004$, Spearman's rho $p=$ 0.021 and MW $p=0.002$ ) (see Table 3).

\section{Results among other health professionals}

The median expectation in the group of other health professionals was that the DCR would improve the health of the PWUD (increase their access to the health care system, decrease at-risk behaviors such as sharing of smoking and injection devices, and decrease both the

Table 2 Results of the expectation questionnaire for the three groups (means; standard deviation)

\begin{tabular}{|c|c|c|c|}
\hline Influence of the DCR & $\begin{array}{l}\text { Opinion of the GP }(N=62) \\
\text { (median; mean) }\end{array}$ & $\begin{array}{l}\text { Opinion of the other health } \\
\text { professionals }(n=82) \\
\text { (median; mean) }\end{array}$ & $\begin{array}{l}\text { Opinion of the PWUD } \\
(N=57) \\
\text { (median; mean) }\end{array}$ \\
\hline Health care access of PWUD & $\begin{array}{l}\text { A bit more } \\
(1 ; 0.85)\end{array}$ & $\begin{array}{l}\text { A bit more } \\
(1 ; 1.15)\end{array}$ & $\begin{array}{l}\text { More } \\
(2 ; 1.25)\end{array}$ \\
\hline Global health an quality of life of PWUD & $\begin{array}{l}\text { Health a bit better } \\
(1 ; 0.85)\end{array}$ & $\begin{array}{l}\text { Health a bit better } \\
(1 ; 1.24)\end{array}$ & $\begin{array}{l}\text { Health a bit better } \\
(1 ; 1.19)\end{array}$ \\
\hline Sharing of used consumption device between PWUD & $\begin{array}{l}\text { Less } \\
(-2 ;-1.50)\end{array}$ & $\begin{array}{l}\text { Less } \\
(-2 ;-1.86)\end{array}$ & $\begin{array}{l}\text { A lot less } \\
(-3 ;-2.09)\end{array}$ \\
\hline Risk of drug-related infection & $\begin{array}{l}\text { Less } \\
(-2 ;-1.73)\end{array}$ & $\begin{array}{l}\text { Less } \\
(-2 ;-1.98)\end{array}$ & $\begin{array}{l}\text { Less } \\
(-2 ;-1.96)\end{array}$ \\
\hline Risk of death by overdose & $\begin{array}{l}\text { A bit less } \\
(-1 ;-1.15)\end{array}$ & $\begin{array}{l}\text { Less } \\
(-2 ;-1.52)\end{array}$ & $\begin{array}{l}\text { Less } \\
(-2 ;-1.79)\end{array}$ \\
\hline Social disadvantages of PWUD & $\begin{array}{l}\text { No influence } \\
(0 ;-0.39)\end{array}$ & $\begin{array}{l}\text { A bit less } \\
(-1 ;-0.68)\end{array}$ & $\begin{array}{l}\text { No influence } \\
(0 ;-0.61)\end{array}$ \\
\hline Frequency of drug use & $\begin{array}{l}\text { No influence } \\
(0 ; 0.35)\end{array}$ & $\begin{array}{l}\text { No influence } \\
(0 ; 0.10)\end{array}$ & $\begin{array}{l}\text { No influence } \\
(0 ; 0.25)\end{array}$ \\
\hline Number of new PWUD & $\begin{array}{l}\text { No influence } \\
(0 ; 0.21)\end{array}$ & $\begin{array}{l}\text { No influence } \\
(0 ; 0.14)\end{array}$ & $\begin{array}{l}\text { No influence } \\
(0 ; 0.11)\end{array}$ \\
\hline Quietness of the neighborhood & $\begin{array}{l}\text { A bit less } \\
(-1 ;-1.03)\end{array}$ & $\begin{array}{l}\text { No influence } \\
(0 ;-0.30)\end{array}$ & $\begin{array}{l}\text { No influence } \\
(0 ; 0.28)\end{array}$ \\
\hline Amount of drug dealing in the neighborhood & $\begin{array}{l}\text { No influence } \\
(0 ; 0.31)\end{array}$ & $\begin{array}{l}\text { No influence } \\
(0 ; 0.10)\end{array}$ & $\begin{array}{l}\text { No influence } \\
(0 ;-0.07)\end{array}$ \\
\hline Number of arrests for drug use & $\begin{array}{l}\text { No influence } \\
(0 ; 0.27)\end{array}$ & $\begin{array}{l}\text { No influence } \\
(0 ;-0.09)\end{array}$ & $\begin{array}{l}\text { A bit less } \\
(-1 ;-0.55)\end{array}$ \\
\hline Violence in the neighborhood & $\begin{array}{l}\text { No influence } \\
(0 ; 0.23)\end{array}$ & $\begin{array}{l}\text { No influence } \\
(0 ;-0.35)\end{array}$ & $\begin{array}{l}\text { A bit less } \\
(-1 ;-0.87)\end{array}$ \\
\hline $\begin{array}{l}\text { Amount of consumption devices abandoned } \\
\text { in the public space }\end{array}$ & $\begin{array}{l}\text { A bit less } \\
(-1 ;-1.07)\end{array}$ & $\begin{array}{l}\text { Less } \\
(-2 ;-1.59)\end{array}$ & $\begin{array}{l}\text { Less } \\
(-2 ;-1.77)\end{array}$ \\
\hline Drug consumption in the public space & $\begin{array}{l}\text { A bit less } \\
(-1 ;-0.84)\end{array}$ & $\begin{array}{l}\text { Less } \\
(-2 ;-1.39)\end{array}$ & $\begin{array}{l}\text { Less } \\
(-2 ;-1.39)\end{array}$ \\
\hline
\end{tabular}




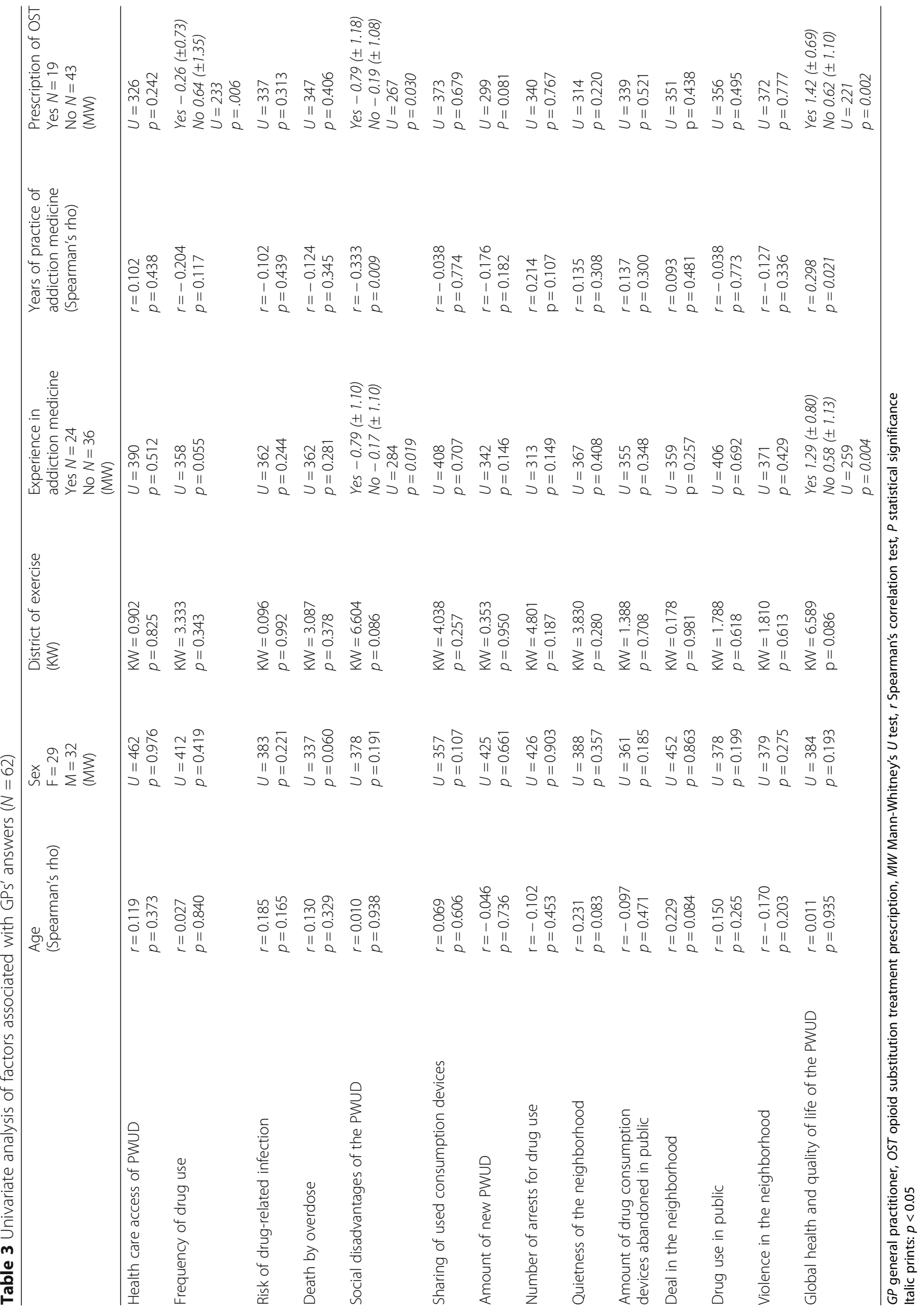


risk of overdose deaths and drug-related infections, resulting in an overall improvement of the global health of the PWUD). The median expectation in this group was that the DCR would have no effect in the access of PWUD to social welfare and that the DCR would have no effect of trivialization and incitement of drug use. The median expectation in this group was also that the DCR would have no effect on drug-related public disorders (tranquility of the neighborhood, violence, number of drug-related arrests) but would have positive effects on other drug-related nuisance (decrease of drug consumption in the public space and of the amount of abandoned smoking and injection devices) (see Table 2).

Inside this group, the univariate analysis revealed a higher heterogeneity than in the group of GPs (see Table 4).

Younger professionals expected a significantly higher decrease in drug-related arrests. Female professionals expected significantly more improvement of health care access for PWUD (MW $p=0.018$ ), a higher reduction in syringe sharing (MW $p<0.001$ ) but less decrease in drug-related arrests (MW $p=0.009$ ) (see Table 4).

In this group, the district of exercise was associated with different expected outcomes of the DCR. Professionals of the 9th district, a little bit farther from the open drug scene and currently less exposed to drug-related nuisance, were the only ones to expect an increase in the frequency of drug use (KW $p=0.026$ ) and drug-related violence (KW $p=0.028$ ) in their neighborhood. The expectation toward a global improvement of the health and well-being of PWUD was also heterogeneous, professionals from the 9th (less concerned) and 18th district (very concerned by open drug use, including a crack cocaine open drug scene) having less positive expectations than professionals working in the 10th and 14th districts (KW, $p=0.041$ ).(see Table 4).

Lastly, we observed that a previous experience in addiction medicine and the duration of this experience was associated with significantly different expectation in this group of other health professionals. Professionals declaring to be experienced in addiction medicine had higher expectations that the DCR would improve the access to social welfare for PWUD (MW $p=0.004$ ), but the higher for those with the fewer years of experience (Spearman's rho, $p=0.022$ ). Furthermore, professionals with an experience in addiction medicine had higher expectations that the DCR would not disturb the quietness of the neighborhood (MW, $p=0.002$ ), and this expectation was higher for those with the most years of experience (Spearman's rho, $p=0.042$ ). Finally, the professionals with experience in addiction medicine had significantly higher expectations that the DCR would decrease drug use in the public space (MW, $p=0.026$ ) and violence in the neighborhood (MW, $p=0.005$ ), and for the latter, this was associated with a longer duration of their experience in the field (Spearman's rho, $p=0.024$ ). (see Table 4).
Among this group of other health professionals, the workplace had a major impact on expectations of the outcome of the opening of a DCR. Professionals working in addiction medicine care or harm reduction centers had significantly higher positive expectances toward the DCR to 8 out of 14 items of the questionnaire than pharmacists, while the medical doctors from the adjacent emergency department had intermediate opinions (see Table 5).

\section{Results among PWUD attending a care or harm reduction center}

The responding PWUD's median expectation was that the DCR would improve the health of attending PWUD (by decreasing the sharing of smoking and injection devices, the number of overdoses-related deaths, and the number of drug-related infectious risk taking and by improving both access to health care system and global health). The median expectation among the groups of responding PWUD was also that the DCR would have no effect on their social welfare. Furthermore, their median expectation was that the DCR would have no effect of trivialization and incitement of drug use and that it would not increase drug-related disorders or drug dealing in the neighborhood. They even expressed that the DCR would decrease the number of drug-related arrests and violence and the number of abandoned smoking and injection devices and also decrease public drug use (see Table 2).

\section{Discussion}

Overall, our results show that the Parisian health care professionals and PWUD from the surroundings of the to-be-created DCR had a positive opinion of its impact, even though its effect on PWUD social rights access was not known or judged ineffective and though the GPs and the pharmacists thought that it could create some mild drug-related public disorders.

The participation of the GP to this study is comparable to most studies involving French GPs. They mainly think that the DCR will have positive effects, which is consistent with the study that showed that $61.5 \%$ of the GPs of the north of Paris were in favor of the DCR [24].Their representations of the effects of the DCR is consistent with the DCRs' objectives and their efficiency as demonstrated in the international literature [1-12, 17, 18], except for the absence of impact on PWUD social rights access. Even though we did not find any study that evaluated the effects of DCRs on the access to social welfare, it is reasonable to expect one given that there is a social worker in the French DCR and that the public health insurance operates on site a basic service to open or extend the rights of the PWUD. 
Table 4 Univariate analysis of factors associated with other health professionals' answers $(N=82)$

\begin{tabular}{|c|c|c|c|c|c|}
\hline & $\begin{array}{l}\text { Age } \\
\text { (Spearman's rho) }\end{array}$ & $\begin{array}{l}\text { Sex } \\
F=47 \\
M=32 \\
(M W)\end{array}$ & $\begin{array}{l}\text { District of exercise } \\
\text { 9th } N=8 \\
\text { 10th } N=36 \\
\text { 18th } N=25 \\
\text { 19th } N=11 \\
\text { (KW) }\end{array}$ & $\begin{array}{l}\text { Experience in addiction } \\
\text { medicine } \\
\text { Yes } N=53 \\
\text { No } N=22 \\
(\text { MW) }\end{array}$ & $\begin{array}{l}\text { Years of practice of } \\
\text { addiction medicine } \\
\text { (Spearman's rho) }\end{array}$ \\
\hline Health care access of PWUD & $\begin{array}{l}r=-0.127 \\
p=0.266\end{array}$ & $\begin{array}{l}F, 1.40( \pm 1.1) \\
M, 0.75( \pm 1.5) \\
U=527 \\
p=0.018\end{array}$ & $\begin{array}{l}\mathrm{KW}=5.498 \\
p=0.139\end{array}$ & $\begin{array}{l}U=461 \\
p=0.136\end{array}$ & $\begin{array}{l}r=0.032 \\
p=0.781\end{array}$ \\
\hline Frequency of drug use & $\begin{array}{l}r=0.077 \\
p=0.504\end{array}$ & $\begin{array}{l}U=691 \\
p=0.680\end{array}$ & $\begin{array}{l}\text { 9th } 1.0 \pm 1.29 \\
10 \text { th }-0.11 \pm 1.0 \\
18 \text { th } 0.48 \pm 1.3 \\
19 \text { th }-0.64 \pm 1.0 \\
K W=9.232 \\
p=0.026\end{array}$ & $\begin{array}{l}U=453 \\
p=0.175\end{array}$ & $\begin{array}{l}r=-0.062 \\
p=0.592\end{array}$ \\
\hline Risk of drug-related infection & $\begin{array}{l}r=-0.165 \\
p=0.148\end{array}$ & $\begin{array}{l}U=692 \\
p=0.526\end{array}$ & $\begin{array}{l}\mathrm{KW}=0.685 \\
p=0.877\end{array}$ & $\begin{array}{l}U=582 \\
p=0.990\end{array}$ & $\begin{array}{l}r=-0.102 \\
p=0.439\end{array}$ \\
\hline Death by overdose & $\begin{array}{l}r=-0.146 \\
p=0.204\end{array}$ & $\begin{array}{l}U=614 \\
p=0.190\end{array}$ & $\begin{array}{l}\mathrm{KW}=0.730 \\
p=0.866\end{array}$ & $\begin{array}{l}U=442 \\
p=0.105\end{array}$ & $\begin{array}{l}r=-0.073 \\
p=0.527\end{array}$ \\
\hline $\begin{array}{l}\text { Social disadvantages of } \\
\text { the PWUD }\end{array}$ & $\begin{array}{l}r=-0.064 \\
p=0.580\end{array}$ & $\begin{array}{l}U=701 \\
p=0.600\end{array}$ & $\begin{array}{l}\mathrm{KW}=5.439 \\
p=0.142\end{array}$ & $\begin{array}{l}\text { Yes }-0.79( \pm 1.10) \\
\text { No }-0.17( \pm 1.10) \\
U=345 \\
p=0.004\end{array}$ & $\begin{array}{l}r=-0.260 \\
p=0.022\end{array}$ \\
\hline $\begin{array}{l}\text { Sharing of used consumption } \\
\text { devices }\end{array}$ & $\begin{array}{l}r=0.063 \\
p=0.584\end{array}$ & $\begin{array}{l}F_{1}-2.38( \pm 0.8) \\
M_{1}-1.06( \pm 1.8) \\
U=410 \\
p=<0.001\end{array}$ & $\begin{array}{l}\mathrm{KW}=2.735 \\
p=0.434\end{array}$ & $\begin{array}{l}U=558 \\
p=0.758\end{array}$ & $\begin{array}{l}r=-0.021 \\
p=0.858\end{array}$ \\
\hline Amount of new PWUD & $\begin{array}{l}r=-0.103 \\
p=0.370\end{array}$ & $\begin{array}{l}U=718 \\
p=0.688\end{array}$ & $\begin{array}{l}\mathrm{KW}=4.344 \\
p=0.227\end{array}$ & $\begin{array}{l}U=486 \\
p=0.177\end{array}$ & $\begin{array}{l}r=-0.137 \\
p=0.231\end{array}$ \\
\hline Number of arrests for drug use & $\begin{array}{l}r=-0.255 \\
p=0.025^{*}\end{array}$ & $\begin{array}{l}F_{1}-0.15( \pm 1.0) \\
M_{1}-0.47( \pm 1.0) \\
U=504 \\
p=0.009\end{array}$ & $\begin{array}{l}\mathrm{KW}=3.632 \\
p=0.304\end{array}$ & $\begin{array}{l}U=450 \\
p=0.113\end{array}$ & $\begin{array}{l}r=-0.198 \\
p=0.084\end{array}$ \\
\hline Quietness of the neighborhood & $\begin{array}{l}r=-0.037 \\
p=0.746\end{array}$ & $\begin{array}{l}U=692 \\
p=0.542\end{array}$ & $\begin{array}{l}\mathrm{KW}=6.259 \\
p=0.100\end{array}$ & $\begin{array}{l}\text { Yes } 0.00( \pm 1.53) \\
\text { No }-1.32( \pm 1.61) \\
U=321 \\
p=0.002\end{array}$ & $\begin{array}{l}r=0.231 \\
p=0.042\end{array}$ \\
\hline $\begin{array}{l}\text { Amount of drug consumption } \\
\text { devices abandoned in public }\end{array}$ & $\begin{array}{l}r=-0.061 \\
p=0.593\end{array}$ & $\begin{array}{l}U=715 \\
p=0.705\end{array}$ & $\begin{array}{l}\mathrm{KW}=2.428 \\
p=0.488\end{array}$ & $\begin{array}{l}U=479 \\
p=0.209\end{array}$ & $\begin{array}{l}r=-0.120 \\
p=0.297\end{array}$ \\
\hline Deal in the neighborhood & $\begin{array}{l}r=0.000 \\
p=0.997\end{array}$ & $\begin{array}{l}U=746 \\
p=0.950\end{array}$ & $\begin{array}{l}\mathrm{KW}=5.794 \\
p=0.122\end{array}$ & $\begin{array}{l}U=428 \\
p=0.060\end{array}$ & $\begin{array}{l}r=-0.069 \\
p=0.547\end{array}$ \\
\hline Drug use in public & $\begin{array}{l}r=0.032 \\
p=0.783\end{array}$ & $\begin{array}{l}U=695 \\
p=0.668\end{array}$ & $\begin{array}{l}\mathrm{KW}=4.612 \\
p=0.203\end{array}$ & $\begin{array}{l}\text { Yes }-1.52( \pm 1.09) \\
\text { No }-0.86( \pm 1.16) \\
U=390 \\
p=0.026\end{array}$ & $\begin{array}{l}r=-0.218 \\
p=0.057\end{array}$ \\
\hline Violence in the neighborhood & $\begin{array}{l}r=-0.078 \\
p=0.503\end{array}$ & $\begin{array}{l}U=668 \\
p=0.481\end{array}$ & $\begin{array}{l}\text { 9th } 0.75 \pm 1.16 \\
10 \text { th }-0.37 \pm 1.26 \\
18 \text { th }-0.40 \pm 1.19 \\
19 \text { th }-1.00 \pm 0.77 \\
K W=9.090 \\
p=0.028\end{array}$ & $\begin{array}{l}\text { Yes } \\
-0.57( \pm 1.11) \\
\text { No } 0.36( \pm 1.12) \\
U=347 \\
p=0.005\end{array}$ & $\begin{array}{l}r=-0.257 \\
p=0.024\end{array}$ \\
\hline $\begin{array}{l}\text { Global health and quality of } \\
\text { life of the PWUD }\end{array}$ & $\begin{array}{l}r=-0.116 \\
p=0.317\end{array}$ & $\begin{array}{l}U=680 \\
p=0.579\end{array}$ & $\begin{array}{l}\text { 9th } 1.0 \pm 0.75 \\
\text { 10th } 1.36 \pm 0.59 \\
\text { 18th } 0.92 \pm 1.13 \\
\text { 19th } 1.73 \pm 0.64 \\
K W=8.247 \\
p=0.041\end{array}$ & $\begin{array}{l}U=461 \\
p=0.131\end{array}$ & $\begin{array}{l}r=0.131 \\
p=0.258\end{array}$ \\
\hline
\end{tabular}


Table 5 Mean expectation scores depending on the workplace in the group of other health professionals $(N=82)$

\begin{tabular}{|c|c|c|c|c|}
\hline (Mean of the answers and Cl 95\%) & $\begin{array}{l}\text { Harm reduction professionals } \\
N=45\end{array}$ & $\begin{array}{l}\text { ER doctors } \\
N=5\end{array}$ & $\begin{array}{l}\text { Pharmacists } \\
N=30\end{array}$ & \\
\hline Health care access of PWUD & $\begin{array}{l}1.62 \\
{[1.40 ; 1.85]}\end{array}$ & $\begin{array}{l}1.40 \\
{[0.72 ; 2.08]}\end{array}$ & $\begin{array}{l}0.40 \\
{[-0.24 ; 1.04]}\end{array}$ & $\begin{array}{l}K W=11.70 \\
p=0.003\end{array}$ \\
\hline Frequency of drug use & $\begin{array}{l}-0.33 \\
{[-0.68 ; 0.01]}\end{array}$ & $\begin{array}{l}0.20 \\
{[-0.36 ; 0.76]}\end{array}$ & $\begin{array}{l}0.76 \\
{[0.31 ; 1.21]}\end{array}$ & $\begin{array}{l}K W=11.62 \\
p=0.003\end{array}$ \\
\hline Risk of drug-related infection & $\begin{array}{l}-2.16 \\
{[-2.49 ;-1.82]}\end{array}$ & $\begin{array}{l}-2.00 \\
{[-2.88 ;-1.12]}\end{array}$ & $\begin{array}{l}-1.70 \\
{[-2.22 ;-1.18]}\end{array}$ & $\begin{array}{l}\mathrm{KW}=2.33 \\
p=0.312\end{array}$ \\
\hline Death by overdose & $\begin{array}{l}-1.73 \\
{[-2.04 ;-1.41]}\end{array}$ & $\begin{array}{l}-1.00 \\
{[-1.88 ;-0.12]}\end{array}$ & $\begin{array}{l}-1.30 \\
{[-1.64 ;-.96]}\end{array}$ & $\begin{array}{l}\mathrm{KW}=6.82 \\
p=0.033\end{array}$ \\
\hline Social disadvantages of the PWUD & $\begin{array}{l}-0.98 \\
{[-1.74 ;-1.30]}\end{array}$ & $\begin{array}{l}-0.80 \\
{[-1.84 ; 0.24]}\end{array}$ & $\begin{array}{l}-0.20 \\
{[-0.56 ; 0.16]}\end{array}$ & $\begin{array}{l}K W=10.74 \\
p=0.005\end{array}$ \\
\hline Sharing of used consumption devices & $\begin{array}{l}-1.73 \\
{[-2.24 ;-1.23]}\end{array}$ & $\begin{array}{l}-2.00 \\
{[-3.24 ;-0.76]}\end{array}$ & $\begin{array}{l}-2.03 \\
{[-2.51 ;-1.56]}\end{array}$ & $\begin{array}{l}\mathrm{KW}=0.37 \\
p=0.830\end{array}$ \\
\hline Amount of new PWUD & $\begin{array}{l}0.02 \\
{[-0.28 ; 0.33]}\end{array}$ & $\begin{array}{l}0.40 \\
{[-0.71 ; 1.51]}\end{array}$ & $\begin{array}{l}0.27 \\
{[0.03 ; 0.51]}\end{array}$ & $\begin{array}{l}\mathrm{KW}=5.30 \\
p=0.070\end{array}$ \\
\hline Number of arrests for drug use & $\begin{array}{l}-0.18 \\
{[-0.53 ; 0.17]}\end{array}$ & $\begin{array}{l}0.00 \\
{[-0.39 ; 0.39]}\end{array}$ & $\begin{array}{l}-0.18 \\
{[-0.53 ; 0.17]}\end{array}$ & $\begin{array}{l}\mathrm{KW}=1.04 \\
p=0.594\end{array}$ \\
\hline Quietness of the neighborhood & $\begin{array}{l}0.42 \\
{[-0.01 ; 0.85]}\end{array}$ & $\begin{array}{l}-1.20 \\
{[-3.24 ; 0.84]}\end{array}$ & $\begin{array}{l}-1.23 \\
{[-1.77 ;-0.70]}\end{array}$ & $\begin{array}{l}K W=20.091 \\
p<0.001\end{array}$ \\
\hline $\begin{array}{l}\text { Amount of drug consumption devices } \\
\text { abandoned in public }\end{array}$ & $\begin{array}{l}-1.84 \\
{[-2.19 ;-1.50]}\end{array}$ & $\begin{array}{l}-1.20 \\
{[-1.76 ;-0.64]}\end{array}$ & $\begin{array}{l}-1.27 \\
{[-1.79 ;-0.74]}\end{array}$ & $\begin{array}{l}K W=6.33 \\
p=0.042\end{array}$ \\
\hline Deal in the neighborhood & $\begin{array}{l}-0.16 \\
{[-0.52 ; 0.21]}\end{array}$ & $\begin{array}{l}1.00 \\
{[-0.24 ; 2.24]}\end{array}$ & $\begin{array}{l}0.33 \\
{[-0.15 ; 0.82]}\end{array}$ & $\begin{array}{l}\mathrm{KW}=5.62 \\
p=0.060\end{array}$ \\
\hline Drug consumption in the public space & $\begin{array}{l}-1.77 \\
{[-2.09 ;-1.45]}\end{array}$ & $\begin{array}{l}-1.20 \\
{[-1.76 ;-0.64]}\end{array}$ & $\begin{array}{l}-0.87 \\
{[-1.30 ;-0.43]}\end{array}$ & $\begin{array}{l}K W=12.603 \\
p=0.002\end{array}$ \\
\hline Violence in the neighborhood & $\begin{array}{l}-0.86 \\
{[-1.20 ;-0.53]}\end{array}$ & $\begin{array}{l}0.80 \\
{[-0.24 ; 1.84]}\end{array}$ & $\begin{array}{l}0.20 \\
{[-0.21 ; 0.61]}\end{array}$ & $\begin{array}{l}K W=20.51 \\
p<0.001\end{array}$ \\
\hline Global health and quality of life of the PWUD & $\begin{array}{l}1.42 \\
{[1.17 ; 1.67]}\end{array}$ & $\begin{array}{l}1.00 \\
{[0.66 ; 1.34]}\end{array}$ & $\begin{array}{l}1.00 \\
{[1.00 ; 1.00]}\end{array}$ & $\begin{array}{l}K W=6.12 \\
p=0.047\end{array}$ \\
\hline
\end{tabular}

PWUD persons who use drugs, ER emergency room, GP general practitioners, $K W$ Kruskall-Wallis test Italic prints: $p<0.05$

The most favorable expectation were found in GPs with a training and current experience in treating patients with substance use disorders.

Other health professionals had also globally positive expectations of the future DCR. Although this group was much more heterogeneous geographically and in the type of professional position, we could observe also that a previous experience in addiction medicine, or currently working in an addiction care or harm reduction facility, was significantly associated with higher expectations. If the pharmacists were expressing significantly less positive expectations of the DCR, they still thought that it would globally reduce risk taking and improve the health and quality of life of PWUD. This is consistent with the findings of previous studies showing French pharmacists opposing to harm reduction policies, perhaps due to a lack of addiction medicine or harm reduction principles and to a general feeling of isolation in their care of PWUD, but changing in the years of opioid substitution treatment access enlargement in France [32].

The low number of ER doctors who participated makes an interpretation of their answer difficult, and their representativity is questionable, but they seem to have globally a good opinion of the DCR in terms of health improvement for PWUD, but at the same time, and because our study only involved the emergency room directly adjacent to the soon to be opened DCR, they thought that it would increase the number of PWUD in their immediate neighborhood and bring more disorders in the public place. On that point, the opinions collected in our study may seem less favorable than those expressed by ER doctors inquired in other countries [31]. But then the question was asked about a putative opening of a DCR in cities that had no such facility, but our study was as far as we are aware of the only study conducted with the precise location of a DCR opening the very next door of the ER where the respondents are employed.

The responding PWUD had a good opinion of the impact of DCR. Their representations are consistent with the objectives of this structure, which means that they understand well the potential benefit of a DCR. This is in accordance with several other studies conducted in different countries were DCR operate [25-30]. The only exception is their disbelief in its social objective efficacy. 
The involvement of PWUD in harm reduction initiatives is essential to ensure harm reduction services reflect their current need, develop trust, and foster their empowerment. [33] Moreover, PWUD have proved that they are able to invest themselves in harm reduction initiatives, and even become influential partners in expanding and improving the local and national harm reduction initiatives [34]. Knowing that they have a positive opinion of the French DCR therefore matters.

The results of this study should be interpreted keeping in mind that it has several limits. First, it would have been more methodologically rigorous to make six separate groups (GP, ER doctor, harm reduction professionals, pharmacists, PWUD) instead of three groups with one "other health professionals" group but we were not sure that we could get enough participants to analyze the answers correctly. Especially, the low number of ER doctors is definitely an obstacle to a correct interpretation of their representations, and other studies should be made to investigate them. Second, there might be a selection bias regarding responding PWUD. Since they were recruited in addiction care/harm reduction facilities, they might be more informed and sensitive to harm reduction, and they might have a better opinion of the DCR than the general population of PWUD in the north of Paris.

Furthermore, because this study was exploratory, we choose not to apply multiple testing corrections to our results and not to calculate the effect size of observed differences. So there is a chance that some results that we observed are false positive.

But our study also has some strength, one of them being that we conducted it when the DCR opening was more than a project but already decided and its future place already known. Furthermore, the opinion of most health professionals regarding DCRs had not been interrogated in France before. Especially the opinion of pharmacists, who are an essential part of the community care system in France, had to our knowledge never been investigated in the international literature. Even though our effectives remain modest, we solicited a large panel of health professionals whose opinions were not known. This study constituted also an opportunity for the Parisian PWUD to express themselves publicly on the controversial subject of the French DCR, making their voice audible being in itself an act of empowerment.

This study was also an opportunity to "take a picture" of the representations of involved people before the opening of an experimental and new structure in France, and it could be interesting to reproduce the same study in a few years to observe if changes occurred in these representation after their confrontation with the real impacts of the French DCR.

\section{Conclusion}

This study shows that shortly before the opening of the first French DCR in Paris, the nearby GPs, pharmacists, ER doctors, harm reduction professionals, and PWUD thought mainly that the DCR would have a positive impact by increasing PWUD's harm reduction behavior and a positive impact on their general health, and no negative impact in terms of increasing drug use. Both professional and PWUD respondents thought that the DCR would have also a positive impact in terms of reducing some drug-related nuisance in the public space. The opinion of all health professionals was significantly better if they were experienced in addiction medicine.

\section{Abbreviations \\ Cl 95\%: Confidence interval of 95\%; DCR: Drug consumption room; ER: Emergency room; GP: General practitioner; HCV: Hepatitis C virus; HIV: Human immunodeficiency virus; MCQ: Multiple choice questionnaire; OST: Opioid substitution treatment; PWUD: People who Use drugs}

\section{Acknowledgements}

The authors would like to thank all the participants who voluntarily participated in this study. We also would like to thank Dr. Elisabeth Avril from the association Gaia for the information she kindly provided on the DCR.

\section{Funding}

No specific funding was received for this study.

\section{Availability of data and materials}

The survey questionnaire used in this article is available upon request. The dataset analyzed during the current study is not available. Participants were assured during the informed consent process that individual responses were confidential.

\section{Authors' contributions}

GC, MF, and FV designed the study. GC and MF developed the questionnaire. GC undertook data collection. GC and FV analyzed the data. GC and FV prepared the first draft of the article. VB and FV edited the revised manuscript. All authors contributed to the revision of the manuscript. All authors read and approved the final manuscript.

\section{Authors' information}

None.

\section{Ethics approval and consent to participate}

All participants were informed of the survey's objectives. This study received the approbation of the ethic committee of INSERM (Institut national de la Santé et de la Recherche Médicale. CEEIIRB00003888) on July 5, 2016.

Consent for publication

Not applicable.

\section{Competing interests}

The authors declare that they have no competing interests.

\section{Publisher's Note}

Springer Nature remains neutral with regard to jurisdictional claims in published maps and institutional affiliations.

\section{Author details}

'Service de médecine addictologique, Hôpital René Muret, APHP, Sevran, France. ${ }^{2}$ Département de Psychiatrie et de Médecine Addictologique, Hôpital Fernand Widal, APHP, Paris, France. ${ }^{3}$ Faculté de Médecine, Université Paris Diderot, Paris, France. ${ }^{4}$ Inserm Umrs1144 Variabilité de Réponse aux Psychotropes, Paris, France. ${ }^{5}$ Association Gaïa, Paris, France. 
Received: 13 June 2018 Accepted: 17 October 2018

Published online: 25 October 2018

\section{References}

1. Hedrich D. European report on drug consumption rooms [Internet]. Office for Official Publications of the European Communities Luxembourg; 2004. Available online: http://www.emcdda.europa.eu/attachements.cfm/att_ 2944_EN_consumption_rooms_report.pdf. Accessed 29 May 2017.

2. Kimber J, Dolan K, van Beek I, Hedrich D, Zurhold H. Drug consumption facilities: an update since 2000. Drug Alcohol Rev. 2003;22(2):227-33.

3. Jozaghi E. "A little heaven in hell": the role of a supervised injection facility in transforming place. Urban Geogr. 2012;33(8):1144-62.

4. Myer AJ, Belisle L. Highs and lows: an interrupted time-series evaluation of the impact of North America's only supervised injection facility on crime. J Drug Issues. 2018:48(1):36-49.

5. European Monitoring Centre for Drugs and Drug Addiction. Drug consumption rooms: an overview of provision and evidence. 2018. Available online: http://www.emcdda.europa.eu/system/files/publications/2734/POD_ Drug\%20consumption\%20rooms.pdf. Accessed 12 Nov 2017.

6. McNeil R, Kerr T, Lampkin H, Small W. "We need somewhere to smoke crack": an ethnographic study of an unsanctioned safer smoking room in Vancouver, Canada. Int J Drug Policy. 2015;26(7):645-52.

7. Potier C, Laprévote V, Dubois-Arber F, Cottencin O, Rolland B. Supervised injection services: what has been demonstrated? A systematic literature review. Drug Alcohol Depend. 2014;145:48-68.

8. Marshall BD, Milloy MJ, Wood E, Montaner JS, Kerr T. Reduction in overdose mortality after the opening of North America's first medically super-vised safer injecting facility: a retrospective population-based study. Lancet. 2011; 377:1429-37.

9. Wood E, Tyndall MW, Zhang R, Montaner JS, Kerr T. Rate of detoxificationservice use and its impact among a cohort of supervised injecting facility users. Addiction. 2007;102:916-9.

10. DeBeck K, Kerr T, Bird L, Zhang R, Marsh D, Tyndall M, Montaner J, Wood E. Injection drug use cessation and use of North America's first medically supervised safer injecting facility. Drug Alcohol Depend. 2011;113:172-6.

11. Kerr T, Tyndall M, Li K, Montaner J, Wood E. Safer injection facility use and syringe sharing in injection drug users. Lancet. 2005;366:316-8.

12. Stoltz JA, Wood E, Small W, Li K, Tyndall M, Montane J, Kerr T. Changes in injecting practices associated with the use of a medically supervised safer injection facility. J Public Health. 2007;29:35-9.

13. Andresen MA, Boyd N. A cost-benefit and cost-effectiveness analysis of Vancouver's supervised injection facility. Int J Drug Policy. 2010;21:70-6.

14. Pinkerton SD. How many HIV infections are prevented by Vancouver Canada's supervised injection facility? Int J Drug Policy. 2011;22(3):179-83.

15. Kerr T, Tyndall MW, Zhang R, Lai C, Montaner JS, Wood E. Circumstances of first injection among illicit drug users accessing a medicallysupervised safer injection facility. Am J Public Health. 2007;97:1228.

16. Salmon AM, Thein HH, Kimber J, Kaldo JM, Maher L. Five years on: what are the community perceptions of drug-related public amenity following the establishment of the Sydney medically supervised injecting centre. Int J Drug Policy. 2007;18:46.

17. Wood E, Tyndall MW, Lai C, Montaner JS, Kerr T. Impact of a medically supervised safer injecting facility on drug dealing and other drug-related crime. Subst Abuse Treat Prev Policy. 2006;1:13.

18. Kennedy MC, Karamouzian M, Kerr T. Public health and public order outcomes associated with supervised drug consumption facilities: a systematic review. Curr HIV/AIDS Rep. 2017;14(5):161-83.

19. Jauffret-Roustide M, Cailbault I. Drug consumption rooms: comparing times, spaces and actors in issues of social acceptability in French public debate. Int J Drug Policy. 2018;56:208-17.

20. INSERM. Expertise collective. Réduction des risques chez les usagers de drogue. Available online: https://www.api-site.paris.fr/mairies/public/assets/ 2017\%2F6\%2FSynthèse\%20du\%20rapport\%20de\%20l\%27INSERM\% 20sur\%20la\%20réduction\%20des\%20risques\%20-\%202010.pdf. Accessed 4 June 2017.

21. Jauffret-Roustide M, Pedrono G, Beltzer N. Supervised consumption rooms: the French paradox. Int J Drug Policy. 2013;24(6):628-30.

22. Cadet-Taïrou A, Gandilhon M. L'usage de sulfate de morphine par les usagers de drogues en France. Tendances récentes 2012-2013. Note 2014-10 (10 juillet 2014) du dispositif Trend et de I'OFDT. Observatoire Français de Drogues et des Toxicomanies, St Denis, France. Available online: https://www.ofdt.fr/BDD/publications/docs/eisxatu7.pdf. Accessed 4 June 2017.

23. Institut national de santé public du Québec (INSPQ). Avis sur la pertinence des services d'injection supervisée : analyse critique de la littérature, 2009. Available online: https://www.inspq.qc.ca/pdf/publications/962_ PertinencelnjecSupervisee.pdf. Accessed 5 June 2017.

24. Clergue-Duval V, Cleirec G, Taroni V, Azuar J. Salle de consommation à moindre risque: les généralistes majoritairement favorables à l'expérimentation. Exercer. 2017;136:346-50.

25. McNeil R, Small W. 'Safer environment interventions': a qualitative synthesis of the experiences and perceptions of people who inject drugs. Soc Sci Med. 2014;106:151-8.

26. Kappel N, Toth E, Tegner J, Lauridsen S. A qualitative study of how Danish drug consumption rooms influence health and well-being among people who use drugs. Harm Reduct J. 2016;13(1):20.

27. Bouvier BA, Elston B, Hadland SE, Green TC, Marshall BDL. Willingness to use a supervised injection facility among young adults who use prescription opioids non-medically: a cross-sectional study. Harm Reduct J. 2017;14(1):13.

28. Mitra S, Rachlis B, Scheim A, Bardwell G, Rourke SB, Kerr T. Acceptability and design preferences of supervised injection services among people who inject drugs in a mid-sized Canadian City. Harm Reduct J. 2017;14(1):46.

29. Butler G, Chapman D, Terry P. Attitudes of intravenous drug users in London towards the provision of drug consumption rooms. Drugs Educ Prev Policy. 2018;25(1):31-7.

30. León C, Cardoso L, Mackin S, Bock B, Gaeta JM. The willingness of people who inject drugs in Boston to use a supervised injection facility. Subst Abus. 2018;39(1):95-101.

31. Katz N, Leonard L, Wiesenfeld L, Perry JJ, Thiruganasambandamoorthy V, Calder L. Support of supervised injection facilities by emergency physicians in Canada. Int J Drug Policy. 2017:49:26-31.

32. Bonnet N, Beauverie P, Gaudoneix-Taïeb M, Poisson N, Imbert E, Fournier G. Changes in pharmacists practices (1996 - 2000) related to harm reduction policy (condoms, injecting equipment, methylmorphine) and maintenance therapy delivery (buprenorphine methadone). Ann Med Interne (Paris). 2001;152(Suppl 7):15-20.

33. Greer AM, Luchenski SA, Amlani AA, Lacroix K, Burmeister C, Buxton JA. Peer engagement in harm reduction strategies and services: a critical case study and evaluation framework from British Columbia, Canada. BMC Public Health. 2016;16:452.

34. Marshall Z, Dechman MK, Minichiello A, Alcock L, Harris GE. Peering into the literature: a systematic review of the roles of people who inject drugs in harm reduction initiatives. Drug Alcohol Depend. 2015;151:1-14.1

\section{Ready to submit your research? Choose BMC and benefit from:}

- fast, convenient online submission

- thorough peer review by experienced researchers in your field

- rapid publication on acceptance

- support for research data, including large and complex data types

- gold Open Access which fosters wider collaboration and increased citations

- maximum visibility for your research: over $100 \mathrm{M}$ website views per year

At BMC, research is always in progress.

Learn more biomedcentral.com/submissions 